\title{
The role of karst in engineering and environmental geosciences
}

\author{
H. C. Ho \\ Department of Geosciences, Mississippi State University \\ Received: 25 January 2011 - Published in Solid Earth Discuss.: 22 February 2011 \\ Revised: 11 August 2011 - Accepted: 13 August 2011 - Published: 30 August 2011
}

\begin{abstract}
Karst is a unique landform developed by soluble rock. It usually relates to the groundwater drainage system, and provides important water resources. Current researches indicate that karst is closely related to the Earth system and environmental protection, and it can also create potential natural hazards such as sinkhole flooding and land subsidence in urban area. Its relationship with hydrogeology has also been an important factor for studying water pollution and nutrient cycles in engineering geosciences and agricultural geology.
\end{abstract}

\section{Introduction}

Karst is a unique landform developed in soluble rock. In modern geology, karst has been described as "the landscape created by dissolution and solution on the soluble rock, such as limestone, halite, and gypsum" (Ford and Williams, 2007, p. 1). During the mid-20th century, the value of karst was usually misinterpreted by the public. The public usually related karst with "show cave", or beautiful tourism spots such as Guilin, China (Mylroie, 1984); however, the extension of karst terrain is much more than that. According to White (1988), "Based on Gvozdetskii research in 1967, approximately $50000000 \mathrm{~km}^{2}$ of land surface could qualify as karst", whereas Palmer (2007) declared that "about 10$15 \%$ of Earth's land area consists of well-developed karst, and this figure is much greater if it includes minor karst, buried paleokarst, and solution porosity formed by deepseated processes". Karst landscapes occur on every continent, especially on North America, Europe, the Middle East, and Southeast Asia (Gunn, 2004). It takes on a very important role in Earth systems, especially in engineering work and environmental changes.

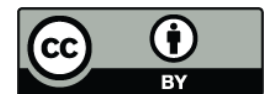

Correspondence to: H. C. Ho (hh455@msstate.edu)

\section{The role of karst in engineering and environmental geosciences}

While geoscientists and geographers have just started to promote environmental concern about karst in the late 20th century, karst actually takes an important role in the Earth Sciences. One of the biggest contributions of karst is how it acts as carbon sink and stores historical climate records on the Earth. Cave researchers discovered that stalagmites can be an indicator of paleoclimate (Cosford et al., 2008; Mylroie, 2008; Yuan et al., 2008). Mylroie suggested that flank margin caves on stable carbonate islands are actually a result of sealevel highstands, and their elevations can act as a paleo-sea level indicator (Mylroie and Carew, 1990; Mylroie and Mylroie, 2009; Walker et al., 2008). More importantly, karst is usually related to water resources, especially on carbonate islands. The position of karst on carbonate islands usually acts as the locator of the freshwater lens. The close relationship of karst with hydrogeology usually attracts the attention of engineering geologists and environmental civil engineers. Traditional concerns on engineering geology are how to detect the aquifer and groundwater discharge of karst systems (Smart and Worthington, 2003; Worthington and Smart, 2003) and how karst integrates with water pollution and land subsidence; while the characteristic of second porosity in karst systems usually increases the infiltration rate and discharge of pollutants, and karst development by dissolution can create unpredictable land surface collapse (Mylroie and Carew, 1997; Waltham and Fookes, 2003; Wilson et al., 1995; Zhou and Beck, 2008).

Therefore, the role of karst environmental geosciences and natural resources management is how these topics act as agents between humans and the environment. The first image of karst for the public usually relates to beautiful geotourism regions such as Guilin, China; but the human-environmental interaction between karst and people needs more study. Current human-environmental interaction studies on karst area

Published by Copernicus Publications on behalf of the European Geosciences Union. 
are focusing on two issues: (1) Result of urbanization on karst terrain, and (2) Feedback of agricultural development on karst regions.

The main concern of urbanization on karst terrain is the relationship of hazards, urban environment and karst processes. In the US, the most serious hazards for urban locations in karst areas are sinkhole flooding and sinkhole collapse. Those hazards usually create property damage and human losses (Waltham and Fookes, 2003; Zhou and Beck, 2008). Rapid urban development in karst regions also increases the surface runoff rate, disrupts groundwater flow and of karst terrain stability, and directly increases the chances of sinkhole flooding and sinkhole collapse (Blansett and Hamlett, 2010; Campbell, 2005; Hart, 2006; Mills et al., 1991; Li et al., 2010a; Waltham and Fookes, 2003; Zhou, 2006; Zhou and Beck, 2008).

In most areas, "sinkhole" can be a dissolution or collapse feature formed by the enlargement of second porosity in carbonate rock. Sinkhole location is difficult to predict. Previous studies indicated that sinkholes can be buried by a thick soil layer, and can also be enlarged by continuing dissolution from infiltration (Waltham and Fookes, 2003; Zhou and Beck, 2008). Furthermore, similar features with different geologic histories in karst such as banana holes, blue holes and pit caves can have the same or more extensive geologic hazard potential. (Mylroie and Carew, 1997; Wilson et al., 1995). Even if there are no sinkholes visible in a karst region, continuing karstic development under urban areas can also affect the stability of building foundations (Chan and Lai, 2005; Darigo, 1989). Rapid urban development on karst usually increases the mass on land surface, which increases the chance of surface collapse; at the same time, the impervious paved surface of urban areas usually blocks water infiltration, which alters the original groundwater flow systems, and results in further karstic development becoming more uncertain.

In addition, urban development on karst areas without careful planning can cause water pollution and aquifer contamination. It usually spreads disease and can break down the chain of the biological cycle (Boulton et al., 2003; Li et al., 2010b).

For agricultural development on karst regions, most concerns of engineering and environmental geologists are how the carbon cycle and the nitrogen and phosphorus cycles integrate with karst and farming (Chen and Lian, 2010; Li et al., 2006; Zhang et al., 2007). Location, storage, usage, and pollution of water resources are also important issues of agricultural engineering and agricultural geology. (Wang et al., 2001; Li et al., 2001b).

Therefore, karst terrain is a complex system with close relationships to Earth system science, engineering geology, hydrogeology, environmental geology and agricultural geology. It takes an important role on the Earth, but the complete image of karst processes for environmental engineering is still being explored. Recent research indicates that geotechnical engineers usually face a technical problem when they build roads, highways and tunnels. The construction usually enlarges the exposed area of karst and increases the rate of karst expression. Methods to mitigate this problem are still being investigated.

Current techniques for investigating karst processes include cave exploration and mapping, dye tracing, geophysical survey, surface mapping, and modeling. Using GIS as an analysis tool has also been a global trend for studying karst. However, the fundamental problem of engineering geology for karst processes is the lack of background information about karst classification. Similar karst features with different geologic histories (such as glaciated karst landscapes and sinkhole plain morphology) are usually misclassified by engineers, especially in landform analysis (Mylroie and Mylroie, 2004; Purkis et al., 2010a; Purkis et al., 2010b; Shinn and Purser, 2010). From the perspective of environmental application of karst analysis, it is necessary to build up a high quality karst geodatabase, with data of karst features, the relationship between karst features, and the relationship of karst features to the current hydrologic situation.

\section{The future}

To investigate karst for engineering and environmental geosciences in the future, here are several developmental suggestions for researchers and engineers:

\subsection{How to investigate a rather large geographically extended karst area without extensive field work?}

Works for the engineering geosciences is usually time limited and without a large support system of instruments and funding. However, accurately investigating karst can be laborbased and expensive. Current engineering works for the karst landscape are usually based on extensive field work. Several researchers are starting to use remote sensing techniques such as LIDAR imaging to support their investigations. However, such work is still expensive and costs time as well. For future investigation, researchers should think about if there is any alternative method to study the landscape, such as using lower resolution images (e.g. LandSAT, SPOT) to detect underground features. Spatial modelling applications with different parameters (such as slope, vegetation, soil moisture) and pixel purity index techniques may also be helpful to investigate the karst features if incorporated into a possible method.

\subsection{How to maintain the data quality?}

Most environmental engineers do not have a very strong background in geology, especially in the understanding of carbonate rock. Therefore, it is necessary to have a better promotion of "karst" to public (especially to engineering firms). It is recommended to have a series of public lectures 
on engineering applications of karst to environmental engineering companies, so as to provide a platform for engineers to understand karst more deeply and maintain the high quality of investigated data in the future. Furthermore, as the recommendation above states, building a high quality global karst geodatabase is necessary. It can minimize the random human errors from different engineers and researchers, and can maximize the sharing platform. The data itself can also be used for future calibrations and support. Therefore, a geodatabase with high quality karst data should be a future goal for development in engineering and the environmental geosciences.

\section{Edited by: A. Cerdà}

\section{References}

Blansett, K. and Hamlett, J.: Challenges of Stormwater Modeling for Urbanized Karst Watersheds, American Society of Agricultural and Biological Engineers Annual International Meeting 2010, 5, 4086-4094, 2010.

Boulton, A. J., Humphreys, W. F., and Eberhard, S. M.: Imperilled subsurface waters in Australia: Biodiversity, threatening processes and conservation, Aquat. Ecosyst. Health, 6(1), 41-54, 2003.

Campbell, W. C.: Complexities of flood mapping in a sinkhole area, Sinkholes and the Engineering and Environmental Impacts of Karst - Proc. 10th Multidisciplinary Conf. Am., Society of Civil Engineers, 470-478, 2005.

Chan, S. H. M. and Lai, K. W.: The Geological Characteristics of Buried Karst and Its Impact on Foundations in Hong Kong, China, Geotech. Sp., 144, 275-285, 2005.

Chen, Y. and Lian, B.: Nitrogen cycle model of agroecosystem in the karst region of Guizhou Province, Chinese Journal of Geochemistry, 29(4), 464-470, 2010.

Cosford, J., Qing, H., Yuan, D., Zhang, M., Holmden, C., Patterson, W., and Hai, C.: Millennial-scale variability in the Asian monsoon: Evidence from oxygen isotope records from stalagmites in southeastern China, Palaeogeogr. Palaeocl., 266(1-2), 3-12, 2008.

Darigo, N. J.: A volcanic breccia in the buried karst of Hong Kong, Engineering and environmental impacts of sinkholes and karst, Proc. 3rd conference, St. Petersburg Beach, FL, 5 1989, 225232, 1989.

Ford, D. C. and Williams, P. W.: Karst Hydrogeology and Geomorphology, Wiley, West Sussex, 2007.

Gunn, J.: Encyclopedia of Caves and Karst Science, Fitzroy Dearborn, New York, 2004.

Hart, E.: Land Use Change and Sinkhole Flooding in Cookeville, Tennessee, Southeastern Geographer, 46(1), 35-50, 2006.

Li, P., Hart, E. A., Mills, H. H., Ho, D. H. C., and Kimbrell, M.: Predicting Sinkhole Flooding in Cookeville, in: Proceedings of the Twentieth Tennessee Water Resources Symposium, 13-15 April 2010, Montgomery Bell State Park, Burns, TN, 1A-7, 2010a.

Li, X., Xiao, H., Wu, J., Su, Y., Huang, D., Huang, M., Liu, S., and Peng, H.: Efects of land use type on soil organic carbon, total nitrogen, and microbial biomass carbon and nitrogen contents in Karst region of South China, Chinese Journal of Applied Ecology, 17(10), 1827-1831, 2006.

Li, X. D., Liu, C. Q., Harue, M., Li, S. L., and Liu, X. L.: The use of environmental isotopic, $\mathrm{C}, \mathrm{Sr}, \mathrm{S}$ and hydrochemical tracers to characterize anthropogenic efects on karst groundwater quality: A case study of the Shuicheng Basin, SW China, Appl. Geochem., 25(12), 1924-1936, 2010b.

Mills, H. H., George, D. B., Taylor, H. N., Ogden, A. E., Robinet-Clark, Y., and Forde, R.: Predicting sinkhole flooding in Cookeville, Tennessee, using SWMM and GIS, in: Appalachian Karst: Proceedings of the Appalachian Karst Symposium, edited by: Kastning, E. H. and Kastning, K. M., National Speleological Society, Huntsville, AL, 1991, 159-167, 1991.

Mylroie, J. E.: Hydrologic classification of caves and karst, in: Groundwater as a Geomorphic Agent, edited by: LaFleur, R. G., Allen \& Unwin, Inc., Boston, MA, 157-172, 1984.

Mylroie, J. E.: Late Quaternary sea-level position: Evidence from Bahamian carbonate deposition and dissolution cycles, Quatern. Int., 183(1), 61-75, 2008.

Mylroie, J. E. and Carew, J. L.: The flank margin model for dissolution cave development in carbonate platforms, Earth Surf. Proc. Land., 15(5), 413-424, 1990.

Mylroie, J. E. and Carew, J. L.: Land use and carbonate karst, in: The engineering geology and hydrogeology of karst terranes, Proc. 6th multidisciplinary conference, Springfeld, 1997, 3-12, 1997.

Mylroie J. E. and Mylroie J. R.: Glaciated karst: How the Helderberg plateau revised the geologic perception, Northeastern Geology and Environmental Sciences, 26(1-2), 82-92, 2004.

Mylroie J. E. and Mylroie, J. R.: Caves as sea level and uplift indicators, Kangaroo Island, South Australia, J. Cave Karst Stud., 71(1), 32-47, 2009.

Palmer, A. N.: Cave Geology, Cave Books, Dayton, 2007.

Smart, C. C. and Worthington, S. R. H.: Electrical conductivity profiling of boreholes as a means of identifying karst aquifers, Geotech. Sp., 122, 265-276, 2003.

Walker, L. N., Mylroie, J. E., Walker, A. D., and Mylroie, J. R.: The caves of Abaco Island, Bahamas: Keys to geologic timelines, J. Cave Karst Stud., 70(2), 108-119, 2008.

Waltham, A. C. and Fookes, P. G.: Engineering classification of karst ground conditions, Q. J. Eng. Geol. Hydroge., 36(2), 101$118,2003$.

Wang, Y., Ma, T., and Luo, Z.: Geostatistical and geochemical analysis of surface water leakage into groundwater on a regional scale: a case study in the Liulin karst system, northwestern China, J. Hydrol., 246(1-4), 223-234, 2001.

White, W. B.: Geomorphology and Hydrology of Karst Terrains, Oxford, New York, 1988.

Wilson, W. L., Mylroie, J. E., and Carew, J. L.: Caves as a geologic hazard: a quantitative analysis from San Salvador Island, Bahamas, in: Karst geohazards: engineering and environmental problems in karst terrane, Proc. 5th conference, Gatlinburg, 1995, 487-495, 1995.

Worthington, S. R. H. and Smart, C. C.: Empirical determination of tracer mass for sink to spring tests in karst, Geotech. Sp., 122, 287-295, 2003.

Yang, Y., Yuan, D., Cheng, H., Qin, J., Lin, Y., Zhang, M., and Zhu, X.: Initial $234^{\mathrm{U}} / 238^{\mathrm{U}}$ variation of stalagmites: Implications for 
paleoclimate reconstruction, Acta Geol. Sin., 82(5), 692-701, 2008.

Zhang, W., Chen, H.-S., Wang, K.-L., Zhang, J.-G., and Hou, Y.: Effects of planting pattern and bare rock ratio on spatial distribution of soil nutrients in Karst depression area, Chinese Journal of Applied Ecology, 18(7), 1459-1463, 2007.
Zhou, W.: Drainage and flooding in karst terranes, Environ. Geol., 51(6), 963-973, 2006.

Zhou, W. and Beck, B. F.: Management and mitigation of sinkholes on karst lands: an overview of practical applications, Environ. Geol., 55, 837-851, 2008 